\title{
DEGRADATION OF PHENOL IN WASTEWATER USING ANOLYTE PRODUCED FROM ELECTROCHEMICAL GENERATION OF BRINE SOLUTION
}

\section{AZNI IDRIS ${ }^{1, *}$ \\ KATAYON SAED ${ }^{2}$}

\author{
${ }^{1}$ Department of Chemical and \\ Environmental Engineering, \\ ${ }^{2}$ Department of Civil Engineering \\ Faculty of Engineering, \\ Universiti Putra Malaysia, \\ 43400 Serdang, Selangor, Malaysia
}

*to whom all correspondence should be addressed

fax: +603-86567099

Accepted: 07/07/03 e-mail: azni@eng.upm.edu.my

\begin{abstract}
This paper presents the degradation of phenol in wastewater using anolyte, which is generated from electrochemical activation process. Anolyte consists of reactive ions and free radicals, which contribute to its oxidizing behavior. The optimum conditions, which facilitate a complete degradation of phenol, were found using variation of dosage of anolyte and reaction time. It was found that about $20 \%$ of anolyte was the optimal dosage which corresponded to $98 \%$ degradation of phenol after a reaction time of 60 minutes. The main products during degradation of phenol by anolyte were found to be benzoquinone, hydroquinone, catechol, maleic acid, fumaric acid and oxalic acid.
\end{abstract}

KEYWORDS: anolyte, electrochemical activation process, phenol degradation, phenol oxidation.

\section{INTRODUCTION}

Widespread contamination of water by phenol has been recognized as an issue of growing importance in recent years. Phenol is potential or known human carcinogen and is of considerable health concern, even at low concentration. For instance, Malaysian guidelines limit phenol concentration to $0.001 \mathrm{mg} \mathrm{l}^{-1}$ in wastewater (DOE, 1974). Hence, the treatment of wastewater containing phenol is a necessity.

Many technologies have been investigated for removing and degradation of phenolic compounds in wastewater. They included, adsorption
(Rengaraj et al., 2002), biodegradation (Miland et al., 1996), UV/Fe $\mathrm{Fe}^{+3}$ (Zhou et al., 2001), extraction by liquid membrane (Lin et al., 1999) and oxidation (Comninellis and Pulgarin, 1991; Tahar and Savall, 1998; Polcaro et al., 1999; Tahar and Savall, 1999, Awad and Abuzaid, 2000).

Among them, oxidation technology has shown their potential to destroy phenol completely in wastewater. In oxidation process, in the first step, the phenol oxidizes to hydroquinone then into benzoquinone and catechol. Subsequent oxidation of these products, after opening of the aromatic ring, leads to the formation of aliphatic carboxylic acids 
such as maleic acid and fumaric acid. When phenol is degraded to aliphatic carboxylic acids the wastewater will become more biodegradable ( $\mathrm{Wu}$ and Zhou, 2001) and less toxic (Pulgarin et al., 1994). The oxidation of phenol by several oxidizing agents such as ozone, UV and hydrogen peroxide has been extensively studied (Gurol and Vatistas, 1987; Esplugas et al., 1994; Shen et al., 1995; Miland et al., 1996; Benitez et al., 2001, Canton et al., 2002).

Apart from those, in recent years there has been increasing interest in the use of catalytic wet oxidation (Maugans and Akgerman, 1997; Larachi, 2001) and wet oxidation (Prakash et al., 2002) for phenol removal. However those methods have some disadvantages and limitations. Sustainability of catalytic wet oxidation technology depends on kinetic regime in which the catalyst life would compromise to its cost. Masende et al. (2002) have reported that total conversion of phenol to $\mathrm{CO}_{2}$ and $\mathrm{H}_{2} \mathrm{O}$ was achieved when the platinum surface was almost oxidized in which it resulted into catalyst deactivation. Wet air oxidation also provides slow and incomplete oxidation, causing the effluent to require further treatment. Supercritical water oxidation has also a very high capital and operating costs due to the extremely harsh operating conditions and the extremely corrosive nature of supercritical water. In other oxidation method such as Horseradish Peroxidase (HRP), in order to achieve a high degree of phenolic removal, large amounts of enzyme are required to counteract the effects of enzyme inactivation, thus limiting its industrial applicability (Klibanov et al., 1980).

The anodic oxidation has also been proposed as an alternative method for phenol degradation, in which the type of anode electrode has been the subject of studies concerning oxidation of phenol, in recent years. Anodic oxidation of phenol on graphite electrode (Awad and Abuzaid, 2000), bismuth doped lead dioxide electrode (Tahar and Savall, 1999), platinum electrode (Comninellis and Pulgarin, 1991), b-lead dioxide electrode (Wu and Zhou, 2001) and tantalum/lead dioxide (Tahar and Salvall, 1998) have been documented. In all previous anodic oxidation methods mentioned above, wastewater containing phenol was pumped into the reactor (cell), while in the present study the aim is to examine the effectiveness of anolyte for degradation of phenol in wastewater outside the reactor. To the authors' knowledge, the use of anolyte as oxidizing agent for phenol destruction has not been investigated to date.

The use of STEL ECA system is gaining popularity as it provides alternative to the use of chlorine gas, ozone and UV-radiation for the treatment of wastewater. The system operates totally without chemical or artificial additives. Only water, regular salt and electrical energy are required to operate the STEL ECA system. As such, there is no detrimental effect on the environment or the ecology and absolutely no pollution or contamination is caused in the purification process. This method eliminates the transportation, storage, and handling of hazardous chemicals and reduces the costs associated with safety procedures, discharge liabilities and environmental exposure.

\section{MATERIAL AND METHODS Characteristic of the STEL ECA system}

Electrochemical activation (ECA) process concept involves the passage of high voltage current through a brine solution with a membrane interposed between the anode and cathode. As a result, this process will produce a substantial electrical potential difference, leading to the generation of two types of water namely anolyte and catholyte. The STEL system comprises an electrolytic cell made of three components: 1) the anode: an outer titanium tube coated internally with a ruthenium oxide, iridium and platinum; 2) the cathode: a central platinum rod coated with pyrocarbon; 3) an acid and alkali resistant ceramic diaphragm coated with oxides of zirconium, yttrium and aluminum fixed between the electrodes to prevent the inter mixing of solutions in the anode and the cathode chambers of the reactor, whilst not obstructing the movement of ions in the electric field. This produces both anolyte and catholyte solutions.

The schematic of the STEL ECA system are shown in Figure 1. The water was supplied at flow rate of $11 \mathrm{~min}^{-1}$. A constant electric current $(18$ volts) is passed through the solution of $\mathrm{NaCl}$ $(10 \%)$. The electron arrival in salt water at the cathode, as well as the discharge of electron from the salt water at anode are accompanied by a series of electrochemical reactions on the cathode and anode surfaces, resulting to the generation of anolyte and catholyte. After about 30 seconds, anolyte and catholyte were collected in two separate beakers. The objective of this work was to investigate the breakdown of phenol in water after they have been treated with anolyte. 


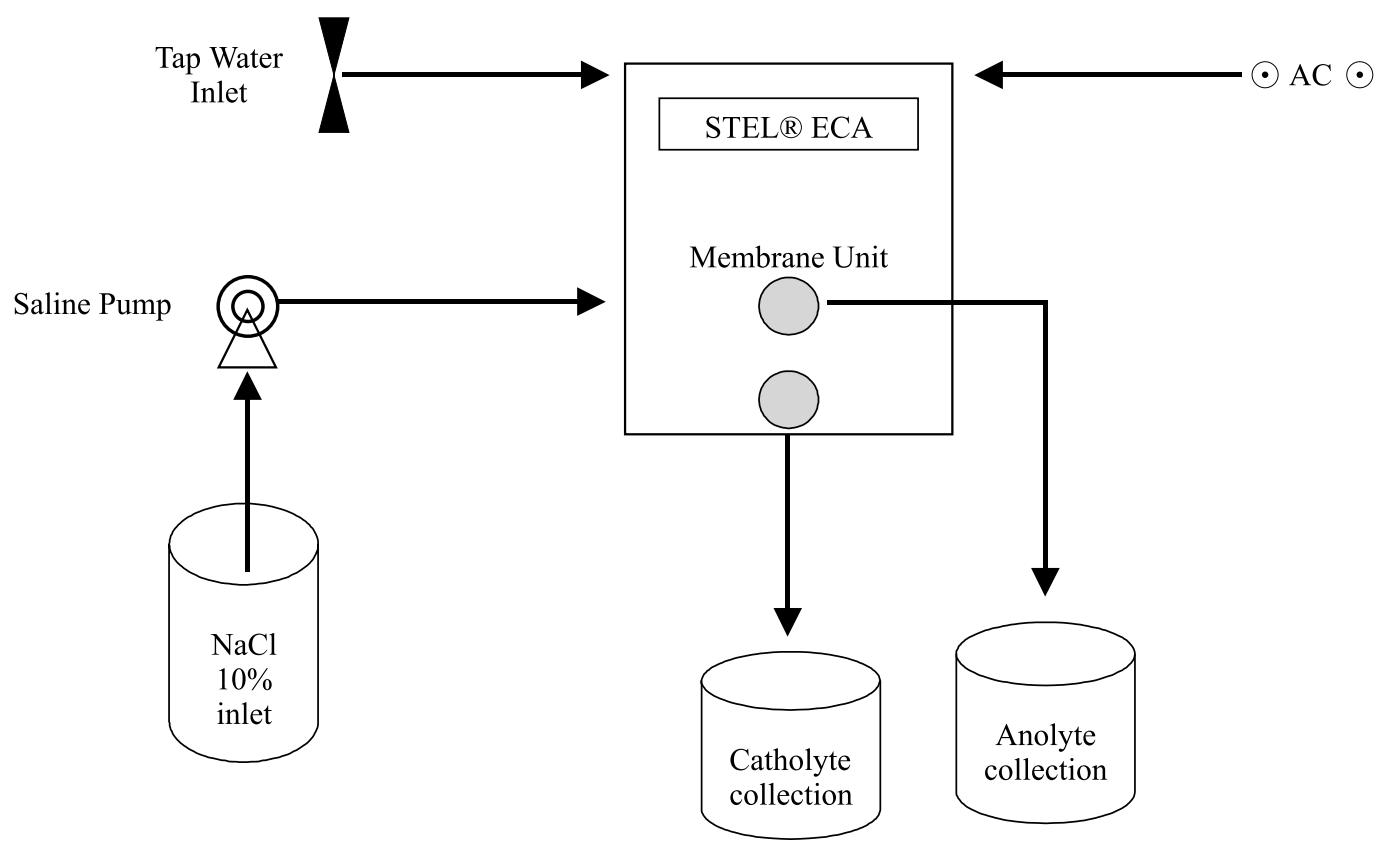

Figure 1. Schematic of ECA process used for producing anolyte

\section{Characteristic of anolyte}

The produced anolyte was colourless liquid with $\mathrm{pH}$ value of 2-3. As shown in Table 1, anolyte contains reactive ions and free radicals, which contribute to the powerful oxidizing properties. Despite its powerful properties, anolyte is nontoxic and harmless to human (Leonov, 1999).

\section{Experimental Set Up}

Experiments were conducted in $500 \mathrm{ml}$ conical flask, each containing $300 \mathrm{ml}$ of phenol solution. Phenol solutions $\left(\mathrm{C}_{\mathrm{i}}=5,10,20,50,100 \mathrm{mg} \mathrm{l}^{-1}\right)$ were prepared from stock detached crystal phenol (Fisher, UK). Nano pure water (Barnstead, USA) was used for preparation of all solutions. Anolyte generated from
ECA system, was added to the phenol solutions in the range of 10 to $100 \mathrm{ml}$. To study the optimal reaction time between anolyte and phenol solutions, the optimal amount of anolyte for the removal of all phenol were added and allowed to remain in contact with the phenol solutions within 10 to $240 \mathrm{~min}$.

\section{Chemical Analysis}

The quantitative analyses of the phenol and its oxidation products were determined using highperformance liquid chromatography (HPLC) and UV detector $(254 \mathrm{~nm})$. The samples were taken at appropriate time intervals and immediately analysed. The separation was performed using a reversed phase column (C18-ODS) at $25^{\circ} \mathrm{C}$ and

Table 1. Reactive ions and free radicals formed in the anolyte solution by elecrochemical activation (Vlyssides et al., 1999; 2000)

\begin{tabular}{|ccc|}
\hline Reactive Molecules & Reactive Ions & Reactive Free Radicals \\
\hline $\mathrm{O}_{3}$ & $\mathrm{H}^{+}$ & $\mathrm{HO}$ \\
\hline $\mathrm{O}_{2}$ & $\mathrm{H} \mathrm{O}^{+}$ & $\mathrm{OH}_{2}$ \\
\hline $\mathrm{H}_{2} \mathrm{O}_{2}$ & $\mathrm{OH}^{-}$ & $\mathrm{O}_{2}$ \\
\hline $\mathrm{ClO}_{2}$ & $\mathrm{ClO}^{-}$ & $\mathrm{O}$ \\
\hline $\mathrm{HClO}$ & $\mathrm{Cl}^{-}$ & $\mathrm{ClO}$ \\
\hline $\mathrm{Cl}_{2}$ & & $\mathrm{Cl}$ \\
\hline $\mathrm{HCl}$ & & \\
\hline $\mathrm{HClO}_{3}$ & & \\
\hline
\end{tabular}




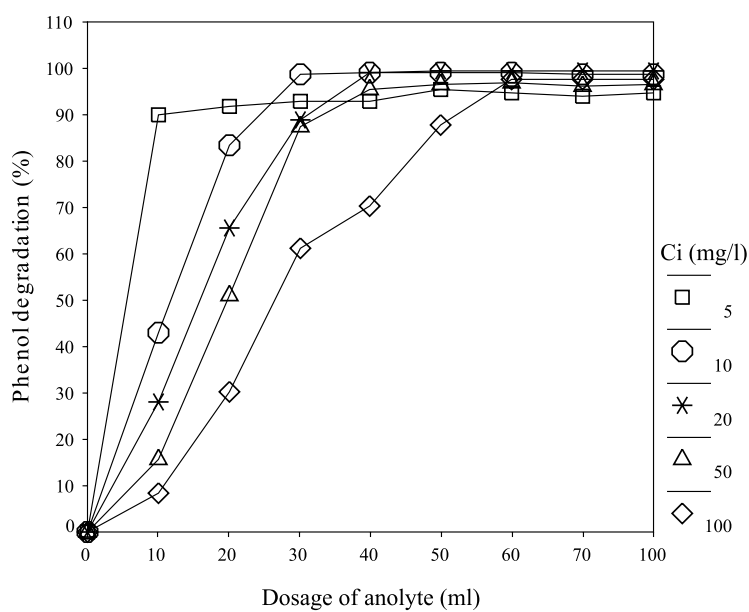

Figure 2. Effect of anolyte dosage on phenol degradarion efficiency (reaction time: $60 \mathrm{~min})$.

flow rate of $1.7 \mathrm{~cm}^{3} \mathrm{~min}^{-1}$, running with mobile phase of acetonitril/water $(\mathrm{v} / \mathrm{v})$ at $60 / 40+0.1 \%$ $\mathrm{H}_{3} \mathrm{PO}_{4}$. The organic acids were determined by ion chromatography with mobile phase of sodium carbonate $\left(0.85 \mathrm{mmol}^{-1}\right)$ and sodium bicarbonate $\left(0.90 \mathrm{mmol} \mathrm{l}^{-1}\right)$ with flow rate of $1.7 \mathrm{~cm}^{3} \mathrm{~min}^{-1}$ at $35^{\circ} \mathrm{C}$ (Wu and Zhou, 2001).

\section{Data Analysis}

The term phenol degradation $(\%)$ is used to quantify the degree of water purification from phenol and is defined as the percentage of phenol removed from solution under the given experimental conditions. Phenol degradation (\%) was calculated as

Phenol degradation $(\%)=\left\{\frac{\mathrm{C}_{\mathrm{o}}-\mathrm{C}}{\mathrm{C}_{\mathrm{o}}} \times 100\right\}$,

where $C_{0}$ and $C$ are initial and final phenol concentrations, respectively.

\section{RESULTS AND DISCUSSION}

Effect of anolyte dosage on phenol degradation The phenol degradation at different dosage of anolyte is illustrated in Figure 2. As shown in Figure 2, increasing the dosage of anolyte up to 60 $\mathrm{ml}$, produced very good removal of phenol (9298\%). However, the phenol degradation rate did not improve when the anolyte was increased from $60 \mathrm{ml}$ to $100 \mathrm{ml}$. Therefore, $60 \mathrm{ml}(20 \%)$ of anolyte was found to be the optimum dose for complete phenol degradation.

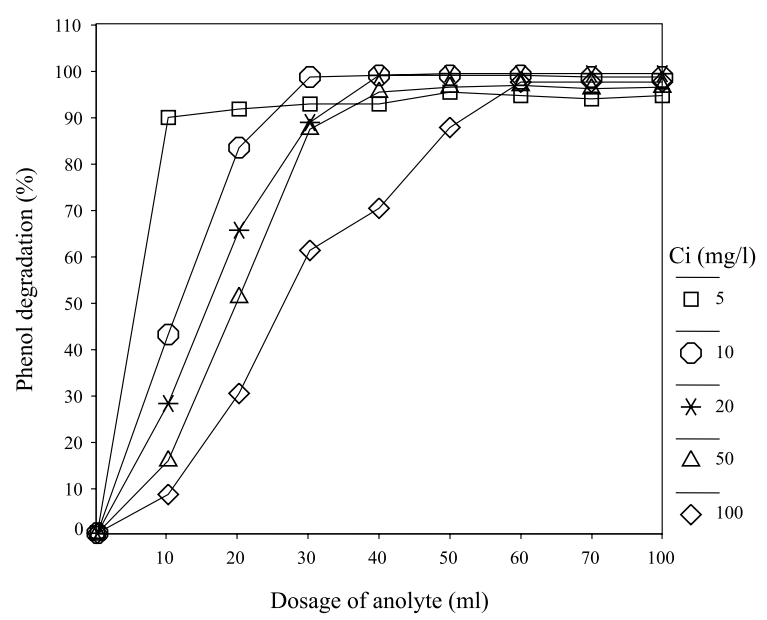

Figure 3. Effect of reaction time on phenol degradarion efficiency (anolyte dosage: $60 \mathrm{~mL}$ )

\section{Effect of reaction time on phenol degradation}

Experiments were carried out to determine the reaction time of phenol with anolyte. Figure 3 shows the effect of reaction time on phenol degradation. As shown in Figure 3, degradation of phenol solutions using low concentration $\left(\mathrm{C}_{\mathrm{i}}=5,10 \mathrm{mg} \mathrm{l}^{-1}\right)$, reached $98 \%$ within 10 minutes of reaction. While, in the case of higher phenol concentrations $\left(C_{i}=20,50,100 \mathrm{mg} \mathrm{l}^{-1}\right)$, 98\% phenol degradation was achieved within $60 \mathrm{~min}$ of reaction time.

A comparison of phenol degradation using anolyte and other oxidizing agents revealed anolyte to be superior. For instance, Gurol et al. (1987) reported only 20 to $60 \%$ phenol degradation within 60 min using ozone and UV process. Others such as Miland et al. (1996) found that 98\% phenol degradation could be achieved after $24 \mathrm{~h}$ upon addition of horseradish peroxidase $\left(1 \mathrm{U} \mathrm{cm}^{-3}\right)$ and $\mathrm{H}_{2} \mathrm{O}_{2}\left(1 \mathrm{mmol} \mathrm{dm}^{-3}\right)$ to a solution of $94 \mathrm{mg} \mathrm{dm}^{-3}$ phenol. While our results showed that $60 \mathrm{~min}$ of reaction time was sufficient to achieve the $98 \%$ of phenol degradation.

\section{Oxidation products}

Chromatography results showed that the main products formed during the reaction of phenol with anolyte were benzoquinone (BQ), hydroquinone (HQ), catechol (CT), maleic acid, fumaric acid and oxalic acid. According to the results presented in Figure 4, the concentration of benzoquinone, hydroquinone and catecol in solution increased within the first $20 \mathrm{~min}$ and then rapidly 


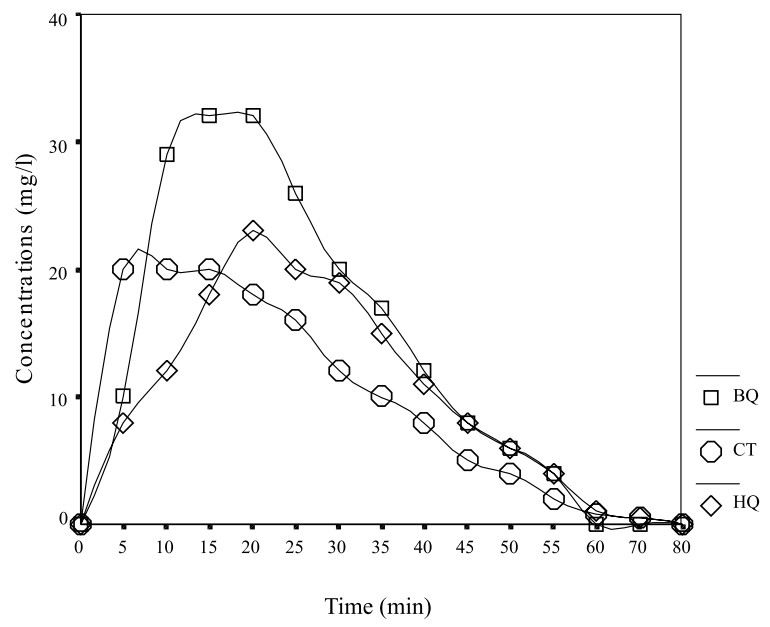

Figure 4. Cyclic products resulted from oxidation of phenol $\left(\mathrm{C}_{\mathrm{i}}=100 \mathrm{mg}^{-1}\right)$ using anolyte.

decrease. It can be also seen that benzoquinone, hydroquinone and catechol are almost disappeared at $60 \mathrm{~min}$ (Figure 4).

This behavior could be due to the attack of free radicals on these compounds and resulting in ring opening reaction to form aliphatic organic acids. In Figure 5, it can be seen that, the concentration of aliphatic organic acids (maleic acid, fumaric acid and oxalic acid) rapidly increases during the first $45 \mathrm{~min}$ and then begins to decrease. Decrease of aliphatic organic acids could be due to mineralisation to $\mathrm{CO}_{2}$ and $\mathrm{H}_{2} \mathrm{O}$ (Fleszar and Ploszynska, 1985; Tahar and Salvall, 1998, 1999; Awad and Abuzaid, 2000; Wu and Zhou, 2001). A comparison of reaction products formed by phenol oxidation using anolyte in this study and other oxidation agents showed that the reaction products are almost the same (Gurol and

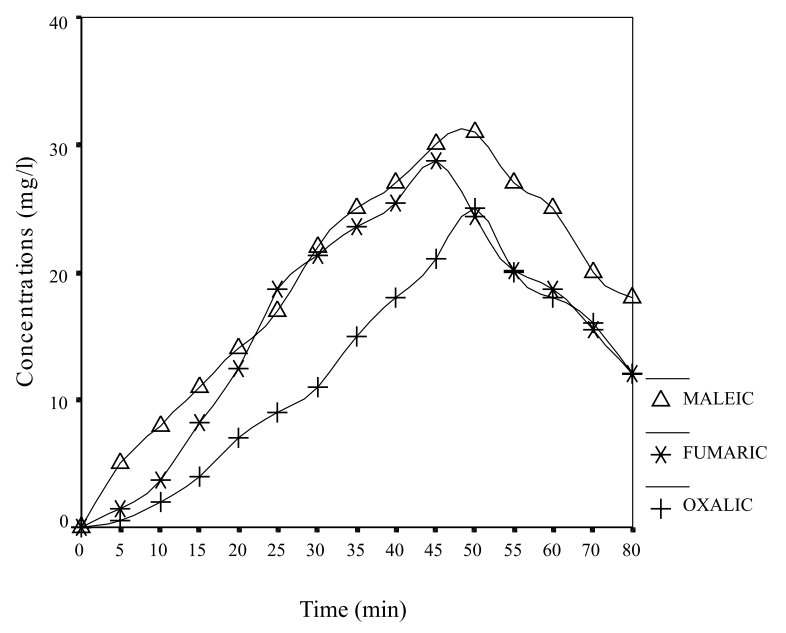

Figure 5. Aliphatic carboxylic acid products resulted from oxidation of phenol $\left(C_{i}=100 \mathrm{mg} \mathrm{l}^{-1}\right)$ using anolyte.

Vatistas, 1987; Esplugas et al., 1994; Shen et al., 1995; Benitez et al., 2001). It implies that all reactions probably occur following the same mechanism, i.e. electrophilic attack of hydroxyl radical on the phenol or its oxidation product.

\section{CONCLUSION}

Degradation of phenol using anolyte produced by electrochemical process was found possible under an optimized condition. The $20 \%$ anolyte was found to be the optimal concentration giving $98 \%$ destruction of phenol after 60 minutes reaction time.

\section{ACKNOWLEDGMENT}

The authors wish to thank Ministry of Science, Technology and Environment of Malaysia for financial support through grant IRPA 51644.

\section{REFERENCES}

Awad, Y.M. and Abuzaid, N.S. (2000), The influence of residence time on the anodic oxidation of phenol, Separation and Purification Technology, 18, 227-236.

Benitez, F.J., Beltran-Heredia, J., Acero, J.L. and Rubio, F.J. (2001), Oxidation of several chorophenolic derivatives by UV irradiation and hydroxyl radicals, Journal of Chemical Technology and Biotechnology, 76, 312-320.

Canton, C., Esplugas, S. and Casado, J. (2002), Mineralization of phenol in aqueous solution by ozonation using iron or copper salts and light, Applied Catalysis, 1320, 1-11.

Comninellis, C. and Pulgarin, C. (1991), Anoxic oxidation of phenol for wastewater treatment, Journal of Applied Electrochemistry, 21, 703-708.

DOE, (1974). Environmental quality (sewage and industrial effluents) regulations, Limits of effluent standard, Department of Environment, Ministry of Science, Technology and Environment, Malaysia.

Esplugas, S., Yue, P.L. and Perez, M.I. (1994), Degradation of 4-chlorophenol by photolytic oxidation, Water Research, 28, 1323-1328. 
Fleszar, B. and Ploszynka, J. (1985), An attempt to define benzene and phenol electrochemical oxidation mechanism, Electrochemica Acta, 30, 31-42.

Gurol, M.D. and Vatistas, R. (1987), Oxidation of phenolic compounds by ozone and ozone-UV radiation: A comparative study, Water Research, 21, 895-900.

Klibanov, A.M., Alberti, B.N., Morris, E.D. and Felshin, L.M. (1980). Enzymatic removal of toxic phenols and anilines from wastewaters, Journal of Applied Biochemistry, 2, 414-421.

Larachi, F. (2001), Neural network kinetic prediction of coke burn-off on spent $\mathrm{MnO}_{2} / \mathrm{CeO}_{2}$ wet oxidation catalysts, Applied Catalysis B: Environmental, 30, 141-150.

Leonov, B.I. (1999), Electrochemical systems for man and mankind, In: Second International Symposium, Electrochemical activation in medicine, agriculture and industry, Moscow, Russia.

Lin, S.H., Pan, C.L. and Leu, H.G. (1999), Liquid membrane extraction of 2-chlorophenol from aqueous solutions, Journal of Hazardous Materials, 65, 289-304.

Masende, Z.P.G., Kuster, B.F.M. Ptasinski, K.J., Janssen, F.J.J.G., Katima, J.H.Y. and Schouten J.C. (2002), Kinetics of the platinum catalyzed wet oxidation of phenol. The role of oxygen and phenol loads. www.epfl.ch/lgrc/camure/abstract/abstract/ABS-049.pdf

Maugans, C.B. and Akgerman, A. (1997), Catalytic wet oxidation of phenol over a $\mathrm{Pt} / \mathrm{TiO}_{2}$ catalyst, Water Research, 31, 3116-3124.

Miland, E., Smyth, M.R. and Fagain, C.O. (1996), Phenol removal by modified peroxidases, Journal of Chemical Technology and Biotechnology, 67, 227-236.

Polcaro, A.M., Palmas, S., Renoldi, F. and Mascia, M. (1999), On the performance of $\mathrm{Ti}^{-\mathrm{SnO}_{2}}$ anodes in electrochemical degradation of 2-chlorophenol for wastewater treatment, Journal of Applied Electrochemistry, 29, 147-151.

Prakash, D.V. and Vijaykumar, V.M. (2002), Insight into sub-critical wet oxidation of phenol, Advances in Environmental Research, 6, 429-439.

Pulgarin, C., Adler, N., Peringer, P. and Comninellis, C.H. (1994), Electrochemical detoxification of 1,4 Benzoquinone solution in wastewater treatment, Water Research, 28, 887-893.

Rengaraj, S., Moon, S.H., Sivablan, R., Arabind, B. and Murugesan, V. (2002), Removal of phenol from aqueous solution and resin manufacturing industry wastewater using an agricultural waste: rubber seed coat, Journal of Hazardous Materials, 89, 185-196.

Shen, Y.S., Ku, Y. and Lee, K.C. (1995), The effect of light absorbance on the decomposition of chlorophenols by ultraviolet radiation and $\mathrm{UV} / \mathrm{H}_{2} \mathrm{O}_{2}$ processes, Water Research, 29, 907-914.

Tahar, N.B. and Savall, A. (1998), Mechanistic aspects of phenol electrochemical degradation by oxidation on a $\mathrm{Ta} / \mathrm{PbO}_{2}$ anode, Journal of Electrochemical Society, 145, 3427-3434.

Tahar, N.B. and Savall, A. (1999), Electrochemical degradation of phenol in aqueous solution on bismuth doped lead dioxide: a comparison of the activities of various electrode formulations, Journal of Applied Electrochemistry, 29, 277-283.

Vlyssides, A.G., Loizidou, M., Karlis, P.K., Zorpas, A.A. and Papaioannou, D. (1999), Electrochemical oxidation of a textile dye wastewater using a Pt/Ti electrode, Journal of Hazardous Materials, B70, 41-52.

Vlyssides, A.G., Papaionnou, D., Loizidoy, M., Kallis, P.K. and Zorpas, A.A. (2000), Testing an electrochemical method for treatment of textile dye wastewater, Waste Management, 20, 569 - 574.

Wu, Z. and Zhou, M. (2001), Partial degradation of phenol by advanced electrochemical oxidation process, Environmental Science and Technology, 35, 2698-2703.

Zhou, M., Wu Z. and Dahui, W. (2001), Promoted UV/Fe ${ }^{+3}$ process for p-nitropheol degradation by electrocatalysis. In: Proceedings of The International Water Association Conference on Water and Wastewater Management for Developing Countries, PWTC, Kuala Lumpur, Malaysia, 29-31 October 2001, Volume 1, pp. 222-237. 